\title{
1. INTRODUCTION AND PRINCIPAL RESULTS: LEG 26 DEEP SEA DRILLING PROJECT
}

\author{
Bruce P. Luyendyk, Woods Hole Oceanographic Institute, Woods Hole, Massachusetts \\ and \\ Thomas A. Davies, Scripps Institution of Oceanography, La Jolla, California
}

\section{CRUISE VITAE}

Leg 26, the fifth cruise of D/V Glomar Challenger in the Indian Ocean, and the first cruise of Phase III of the Deep Sea Drilling Project, began when the ship sailed from Durban, South Africa, on 6 September 1972 and ended when we docked in Fremantle, Western Australia, 30 October. During the course of Leg 26, Glomar Challenger steamed 5530 miles $(9447 \mathrm{~km})$ and drilling operations were carried out at nine sites drilling 12 holes in water depths ranging from 1144 to 5361 meters (Figure 1). Routine underway measurements were made between sites. These included echo-sounding, seismic reflection profiling (airgun), and magnetic field measurements. At the nine sites occupied, a total of 246 cores were cut representing 2224.5 meters of section, or $62 \%$ of the total stratigraphic section penetrated; 1177.7 meters of core material were recovered, an overall recovery of $53 \%$. Basement was reached at six sites, and a total of 69.9 meters of igneous rock cores recovered. Total penetration into igneous rock was 152.7 meters. Locations of the sites, dates of occupation, and other pertinent details are given in Table 1 .

\section{GENERAL BACKGROUND}

The Indian Ocean is the smallest of the three major ocean basins but appears to be geologically the most complex. Some of the important features are shown in

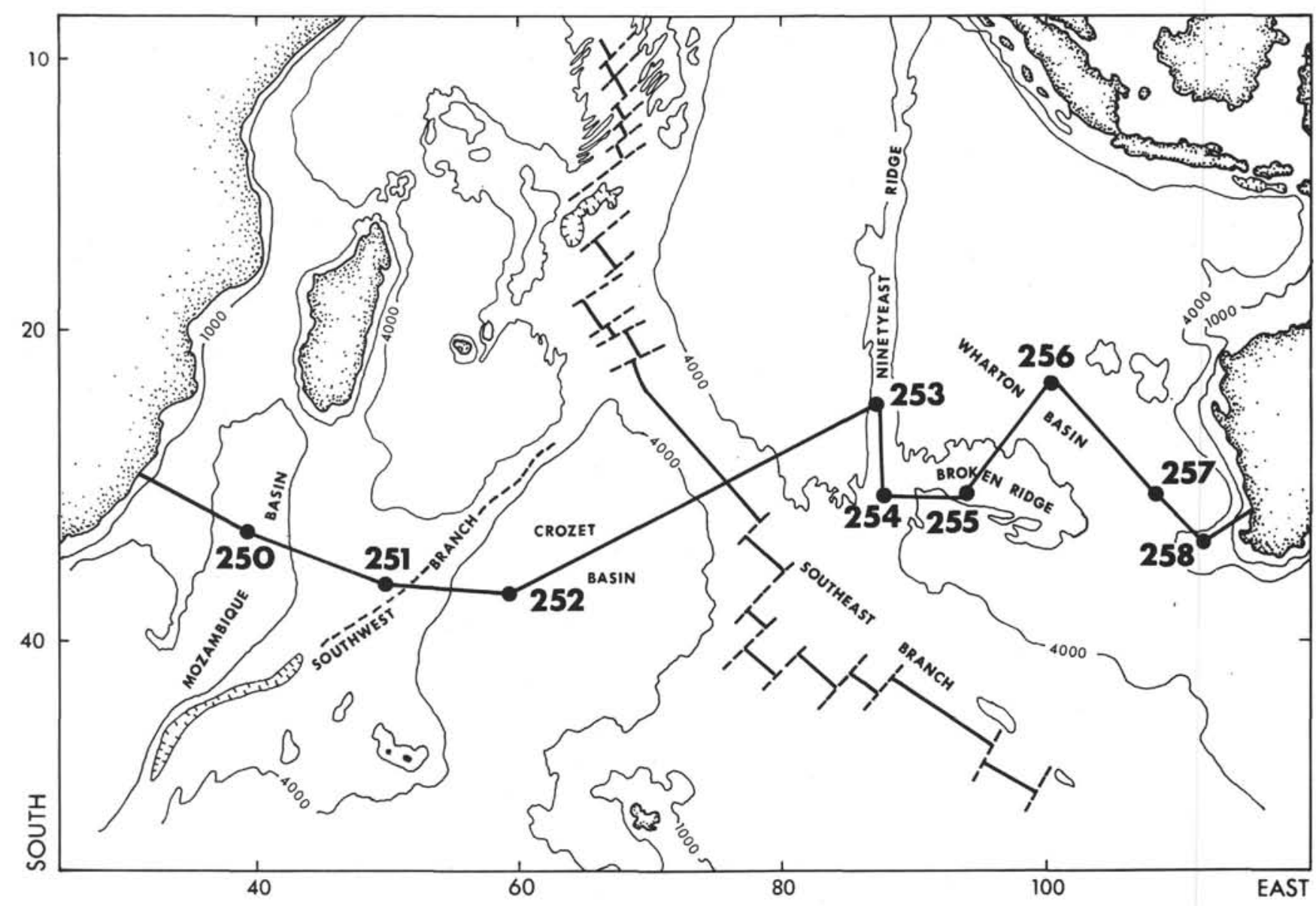

Figure 1. Sites occupied on Leg 26.

'Now at Department of Geological Sciences University of California, Santa Barbara, Santa Barbara, California. 
TABLE 1

Summary of Holes Drilled on Leg 26

\begin{tabular}{|c|c|c|c|c|c|c|c|c|c|}
\hline \multirow[b]{2}{*}{ Hole } & \multicolumn{2}{|c|}{ Position } & \multirow[b]{2}{*}{ Dates of Drilling } & \multirow{2}{*}{$\begin{array}{l}\text { Water } \\
\text { Depth } \\
\text { (corr. m) }\end{array}$} & \multirow{2}{*}{$\begin{array}{l}\text { Pene- } \\
\text { tration } \\
\text { (m) }\end{array}$} & \multirow{2}{*}{$\begin{array}{l}\text { No. } \\
\text { Cores } \\
\text { Cut }\end{array}$} & \multirow{2}{*}{$\begin{array}{c}\text { Total } \\
\text { Cored } \\
\text { (m) }\end{array}$} & \multirow{2}{*}{$\begin{array}{c}\text { Total } \\
\text { Recovered } \\
\text { (m) }\end{array}$} & \multirow{2}{*}{$\begin{array}{c}\text { Recovery } \\
\text { (\%) }\end{array}$} \\
\hline & Latitude & Longitude & & & & & & & \\
\hline 250 & $33^{\circ} 27.74^{\prime} \mathrm{S}$ & $39^{\circ} 22.15^{\prime} \mathrm{E}$ & 9-10 Sept. 1972 & 5119 & 65.0 & 3 & 28.0 & 21.45 & 77 \\
\hline $250 \mathrm{~A}$ & $33^{\circ} 27.74$ 'S & $39^{\circ} 22.15^{\prime} \mathrm{E}$ & 11-14 Sept. 1972 & 5119 & 738.5 & 26 & 240.5 & 124.4 & 52 \\
\hline 251 & $36^{\circ} 30.26^{\prime} \mathrm{S}$ & $49^{\circ} 29.08^{\prime} \mathrm{E}$ & 17-18 Sept. 1972 & 3489 & 87.5 & 10 & 87.5 & 67.2 & 77 \\
\hline $251 \mathrm{~A}$ & $36^{\circ} 30.26^{\prime} \mathrm{S}$ & $49^{\circ} 29.08^{\prime} \mathrm{E}$ & 18-21 Sept. 1972 & 3489 & 499.0 & 31 & 276.5 & 158.38 & 57 \\
\hline 252 & $37^{\circ} 02.44^{\prime} \mathrm{S}$ & $59^{\circ} 14.33^{\prime} \mathrm{E}$ & 23-24 Sept. 1972 & 5032 & 247.0 & 7 & 57.0 & 41.5 & 73 \\
\hline 253 & $24^{\circ} 52.65^{\prime} \mathrm{S}$ & $87^{\circ} 21.97^{\prime} \mathrm{E}$ & 1-5 Oct. 1972 & 1962 & 559.0 & 58 & 536.5 & 270.1 & 50.3 \\
\hline 254 & $30^{\circ} 58.15^{\prime} \mathrm{S}$ & $87^{\circ} 53.72^{\prime} \mathrm{E}$ & 7-9 Oct. 1972 & 1253 & 343.5 & 38 & 329.0 & 150.5 & 45.7 \\
\hline 255 & $31^{\circ} 07.87^{\prime} \mathrm{S}$ & $93^{\circ} 43.72^{\prime} \mathrm{E}$ & $11-12$ Oct. 1972 & 1144 & 108.5 & 11 & 99.0 & 7.9 & 8 \\
\hline 256 & $23^{\circ} 27.35^{\prime} \mathrm{S}$ & $100^{\circ} 46.46^{\prime} \mathrm{E}$ & 15-17 Oct. 1972 & 5361 & 270.0 & 11 & 99.0 & 78.4 & 79 \\
\hline 257 & $30^{\circ} 59.16^{\prime} \mathrm{S}$ & $108^{\circ} 20.99^{\prime} \mathrm{E}$ & 20-23 Oct. 1972 & 5278 & 326.5 & 17 & 155.5 & 76.7 & 49 \\
\hline 258 & $33^{\circ} 47.69^{\prime} \mathrm{S}$ & $112^{\circ} 28.42^{\prime} \mathrm{E}$ & 25-28 Oct. 1972 & 2793 & 525.0 & 25 & 230.5 & 115.55 & 50 \\
\hline \multirow[t]{2}{*}{$258 \mathrm{~A}$} & $33^{\circ} 47.69^{\prime} \mathrm{S}$ & $112^{\circ} 28.42^{\prime} \mathrm{E}$ & 28-29 Oct. 1972 & 2793 & 123.5 & 9 & 85.5 & 65.5 & 77 \\
\hline & Total & & & & 3893.0 & 246 & 2224.5 & 1177.7 & 53 \\
\hline
\end{tabular}

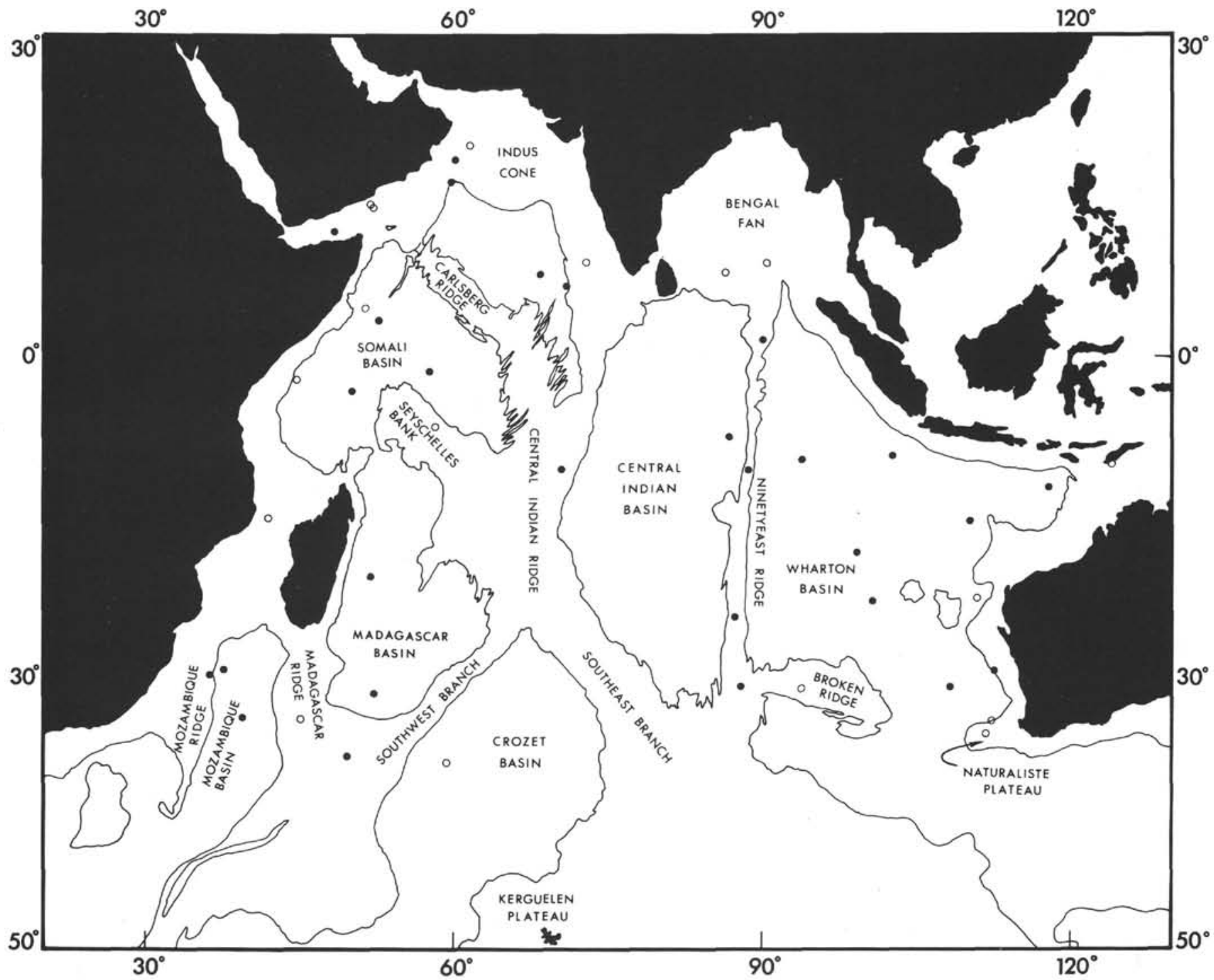

Figure 2. Physiographic features of the Indian Ocean, as defined by the 4000-meter contour. Some of the features commonly referred to are named. Solid circles = DSDP sites reaching basement; open circles = other DSDP sites. 
Figure 2. The dominant feature is the mid-ocean ridge system which has the form of an inverted Y. The Southeast Branch of the ridge joins with the Pacific-Antarctic Ridge. Sea-floor spreading from this ridge has separated Australia from Antarctica since the Eocene. The Southwest Branch is less well known but appears to be much more complex, being cut by many north-northeasttrending fracture zones.

An interesting feature of the Indian Ocean is the occurrence of many asseismic ridges and plateaus. Perhaps the most striking of these is the Ninetyeast Ridge which extends along the $90^{\circ} \mathrm{E}$ meridian from $30^{\circ} \mathrm{S}$ to the Bay of Bengal. Ninetyeast Ridge has been shown to have a shallow water, volcanic origin but other asseismic features, e.g., Broken Ridge, Kerguelen Plateau, have been regarded as continental fragments left behind as the surrounding continents separated. Despite several drilling attempts, the origin of many of these features remains obscure.

The distribution of sediments in the Indian Ocean has been described by Ewing et al. (1969). Their results, based on extensive study of seismic reflection records, are shown in Figure 3. The major thickness of sediments is found in the Ganges and Indus cones and in the basins off the east coast of Africa. The controlling influence of physiography on sediment distribution is clearly shown. The southern part of the Central Indian Basin, for example, is virtually devoid of sediment because of its isolated position, as is the western side of the Wharton Basin.

In contrast to the relatively simple opening of the north and south Atlantic, the formation of the Indian Ocean is believed to follow a very complicated history. Relative motions between five lithospheric plates-Africa, Antarctica, Madagascar, India, and Australia-have taken place since the mid-Mesozoic. The concept of Gondwanaland, or the ancient form of the Indian Ocean continents, is well known. However, the history of how these continents were broken apart and separated to form the Indian Ocean is poorly known and speculative. McKenzie and Sclater (1971) used Cenozoic marine magnetic anomalies to reconstruct the relative positions since the Late Cretaceous of the plates belonging to the Indian Ocean system. But because the earth's field is not believed to have reversed during the mid to Late Cretaceous (Larson and Pitman, 1972), magnetic stripes or isochrons for this period do not exist, and plate motions cannot be determined by magnetic charting of the sea floor. As McKenzie and Sclater pointed out, the history of the early formation of the Indian Ocean (pre Late Cretaceous) must therefore be deduced from the results of drilling at judiciously placed sites in areas of ocean crust devoid of magnetic lineations.

\section{PROBLEMS INVESTIGATED ON LEG 26}

The Indian Ocean south of $20^{\circ} \mathrm{S}$ is considerably less well known than the more northerly part. The sites drilled on Leg 26 were selected to try to elucidate a number of specific problems of both local and broad regional significance, as well as to add to our general knowledge of the area. Briefly, the particular problems selected were:

1) To locate the oldest sediment in the Indian Ocean and thus possibly the date of the initial breakup of Gondwanaland (Sites 250, 256, 257);

2) To determine the effects of the initiation of the Circumpolar Current on southern Indian Ocean sedimentation (Sites 250, 252, 256, 257, 258);

3) To determine the history of spreading of the Southwest Branch of the Indian Ocean Ridge and the history of the crust and oceanic sedimentation in that general region (Sites 250, 251, 252);

4) To further examine the nature and history of the Ninetyeast Ridge (Sites 253, 254);

5) To determine the age, nature, and history of Broken Ridge-Naturaliste Plateau, supposed microcontinents (Sites 255, 258).

The realization of the crucial role of deep-sea drilling in the determination of the pre-Tertiary history of the Indian Ocean region led in large part to drilling Sites 250, 256 , and 257 . The age at Site 250 would aid in determining when Africa and Antarctica separated. Sites 256 and 257 in the Wharton Basin were also to search for old crust, but the problem here was somewhat more complicated. It was previously suggested by Dietz and Holden (1971) that the pre-Mesozoic configuration of Gondwanaland exhibited an oceanic gap between the present Indian and Australian continents. Presumably then, the oceanic crust off Australia was much older, say Permian or Triassic in age. This could be tested by drilling at Sites 256 and 257, although this hypothesis had already been somewhat discredited by the recovery of Late Cretaceous sediments on Leg 22 (von der Borch, Sclater, et al., 1974) in the northern Wharton Basin. Another question concerning early Indian Ocean history was the ancient position of India in Gondwanaland; was it originally against West Australia (Veevers et al., 1971, Crawford, 1969) or against Antarctica (e.g., DuToit, 1937). By mapping the crustal age gradients off West Australia, Sites 256 and 257 also addressed this question.

One important effect of the breakup of Gondwanaland was the creation of the Circumpolar Current. It is probably reasonable to assume that this event followed the rifting of Australia from Antarctica in the early Eocene (Weissel and Hayes, 1971). The effects of the initiation of this current on sedimentation are uncertain, but sites on pre-Eocene crust could tell part of the story.

Another sedimentologic problem, perhaps related to changes in oceanic circulation, which was coming into focus near the time of planning Leg 26 , was a possible deep-sea unconformity or dissolution facies centered on the Oligocene. This phenomenon was observed in the western Pacific (Leg 21, Kennett et al., 1972); equatorial Indian Ocean (Leg 22, von der Borch, Sclater, et al., 1974); and western Indian Ocean (Leg 25, Simpson, Schlich, et al., in press). Does this unconformity extend to the areas of Leg 26 sites? Besides this question, it could also be asked whether the Late CretaceousPaleocene unconformity observed in the Pacific (Douglas et al., 1973) could also be observed in the 


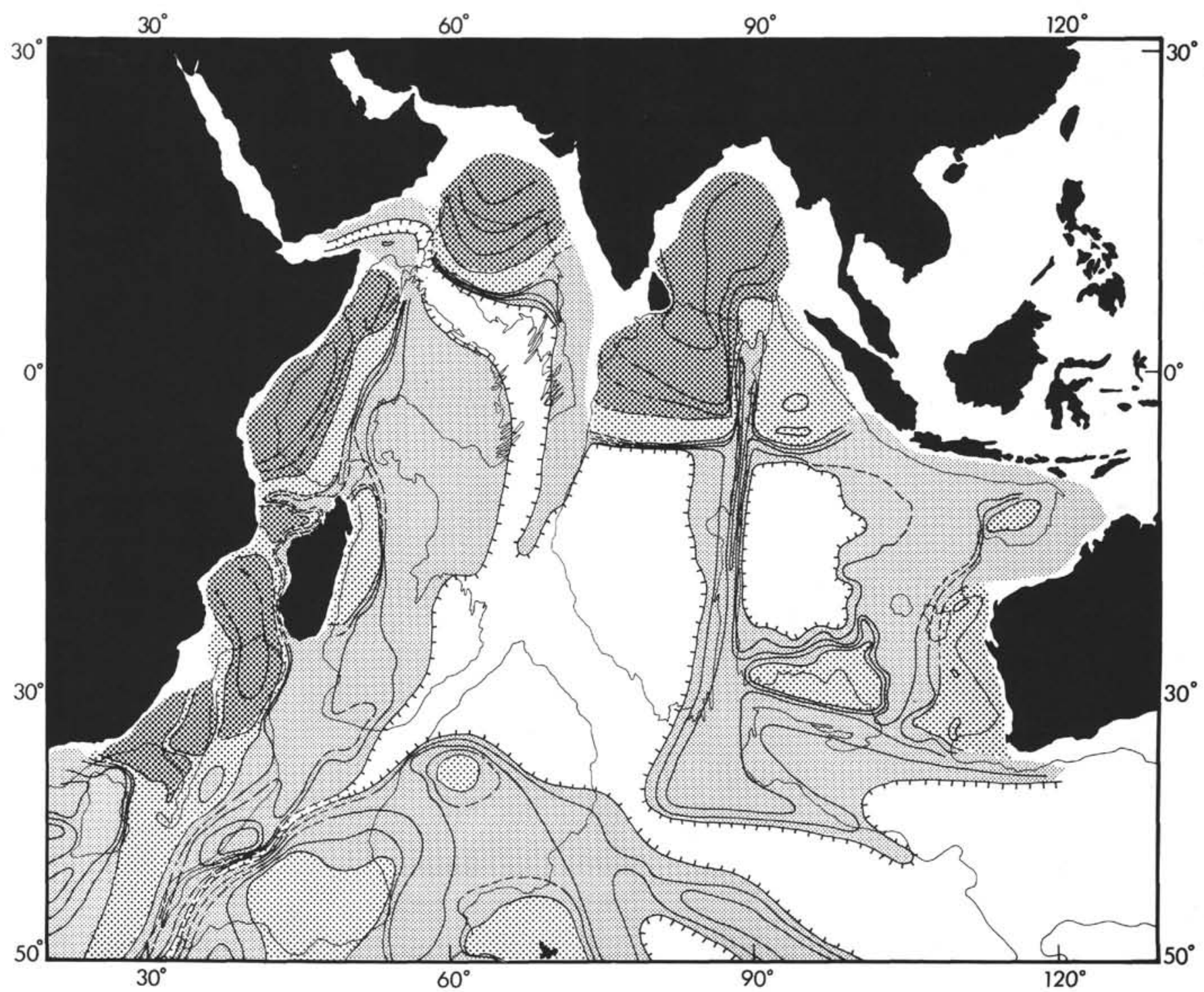

Figure 3. Distribution of sediments in the Indian Ocean, based on seismic reflection data. Blank $=$ sediment thickness less than $0.1 \mathrm{sec}$; light stipple $=0.1-0.5 \mathrm{sec}$; coarse stipple $=0.5-1.0 \mathrm{sec}$; heavy stipple $=$ greater than $1.0 \mathrm{sec}$. $($ Modified from Ewing et al., 1969).

Indian Ocean. Leg 26 was well suited to examine this latter possibility since many sites were planned in crust believed to be of Late Cretaceous or older age.

The age of the Southwest Branch of the Indian Ocean ridge as an active spreading center was uncertain, besides the age of the crust in this part of the Indian Basin. Magnetic anomalies over the ridge are very poorly developed and only indicate an approximate spreading rate near $1.0 \mathrm{~cm} / \mathrm{yr}$ (McKenzie and Sclater, 1971). Best estimates of the age of this structure ranged from early to middle Oligocene (op. cit.). The uplift of the Southwest Branch also may have had an effect on bottom water circulation which would subsequently be revealed in nearby sediment sections.

The Ninetyeast Ridge is a unique sea-floor structure. Similar features have not been found in any other world ocean basin. First discovered and delineated during the International Indian Ocean Expedition, the ridge extends from $31^{\circ} \mathrm{S}$ to $15^{\circ} \mathrm{N}$ approximately parallel to the $90^{\circ} \mathrm{E}$ meridian and has a relief of about 2000 meters above the surrounding sea floor. This feature has been variously described as a microcontinental fragment (Heezen and Tharp, 1965); an uplifted fault block of ocean crust (Francis and Raitt, 1967; LePichon and Heirtzler, 1968; McKenzie and Sclater, 1971, Falvey, 1972); a trace of a mantle convection plume or hot spot (Morgan, 1972); or an ancient transform fault between the Indian and Australian and/or Wharton plates (McKenzie and Sclater, 1971; Falvey, 1972). By the time Leg 26 sailed, Leg 22 results from the Ninetyeast Ridge indicated that the structure has a shallow-water volcanic origin. Our sites $(253,254)$ were planned to augment this observation and to try to determine whether its origin was more related to transform faulting or mantle plume activity.

Broken Ridge and the Naturaliste Plateau are other features which were popularly regarded as microcontinental fragments at the time of Leg 26 (Heezen and 
Tharp, 1965). Francis and Raitt (1967) showed that the crust forming Broken Ridge has continent-like thickness and seismic structure, while the obvious connection of the Naturaliste Plateau to the Australian continental margin suggests its origin. To determine whether these two structures are genetically related was one of our drilling objectives. Furthermore, if Broken Ridge is continental in origin, complications are introduced in the configuration of Gondwanaland which most reconstructions ignore.

Finally, we should point out that the Leg 26 sites occupy a unique niche in the scientific program for drilling in the Indian Ocean. In traversing the southern Indian Ocean, Leg 26 touched on the perimeters of regional investigations carried out on Leg 25 in the west, Leg 22 on the Ninetyeast Ridge, and Legs 22 and 27 in the eastern basin. Consequently, Leg 26 was planned to amplify and extend the results of these other cruises.

\section{PRINCIPAL RESULTS AND CONCLUSIONS}

The major results of our program and their implications are discussed in detail in the following chapters of this volume and summarized in the leg synthesis, Chapter 36, and in a large graphic summary at the back of the book. Below we have extracted some of the more cogent points:

1) Crustal ages appear to be not much older than mid Cretaceous in the southwestern Indian Ocean and Early Cretaceous in the eastern basin. In the east, age gradients seem to support a position for India against Antarctica in the reconstruction of Gondwanaland, but the drilling results are somewhat equivocal in this regard.

2) Simple effects of the initiation of the Circumpolar Current on sedimentation are not seen. However, our data support the existence of unconformities and/or dissolution facies centered on the Oligocene and on the Late Cretaceous to Paleocene in many areas of the Indian Ocean.

3) The Southwest Branch of the Indian Ocean Ridge is spreading at about $0.9 \mathrm{~cm} / \mathrm{yr}$ near Site 251 and is no older than Eocene. Uplift of this structure has affected sedimentation at Sites 245, 250, and 252 .

4) Sites on the Ninetyeast Ridge confirmed Leg 22 results that this structure is a volcanic feature, formed in shallow water, which is older to the north. The implications of our results concerning the relative contribution of transform faulting and/or mantle plume activity to the origin of the Ninetyeast Ridge are still unclear.

5) Broken Ridge and the Naturaliste Plateau drilling results show a history of vertical motions for these structures since the mid to Late Cretaceous. These are related to tectonics of Australia and Antarctica.
Although basement was not sampled on either structure, sedimentary facies seem to support an oceanic volcanic origin for both features.

\section{REFERENCES}

Crawford, A. R., 1969. India, Ceylon and Pakistan: new age data and comparisons with Australia: Nature, v. 223, p. 380-383.

Dietz, R. S. and Holden, J. C., 1971. Pre-Mesozoic oceanic crust in the Eastern Indian Ocean (Wharton Basin): Nature, v. 229, p. 307-312.

Douglas, R. G., Roth, P. H., and Moore, T. C., Jr., 1973. Biostratigraphic synthesis: hiatuses and unconformities. In Winterer, E. L., Ewing, J. I., et al., Initial Reports of the Deep Sea Drilling Project, Volume 17: Washington (U.S. Government Printing Office), p. 905-909.

DuToit, A. L., 1937. Our wandering continents: Edinburgh (Oliver and Boyd).

Ewing, M., Eittreim, S., Truchan, M., and Ewing, J. I., 1969. Sediment distribution in the Indian Ocean: Deep Sea Res., v. 16 , p. $231-248$.

Falvey, D. A., 1972. Sea floor spreading in the Wharton Basin (Northeast Indian Ocean) and the breakup of eastern Gondwanaland: Australian Petrol. Explor. Assoc. J., v. 12, p. 86-88.

Francis, T. F. G. and Raitt, R. W., 1967. Seismic refraction measurements in the southern Indian Ocean: J. Geophys. Res., v. 72, p. 3015-3042.

Heezen, B. C. and Tharp, M., 1965. Tectonic fabric of the Atlantic and Indian Oceans and continental drift: Phil. Trans. Roy. Soc. London, v. 258, p. 90-106.

Kennett, J. P., Burns, R. E., Andrews, J. E., Churkin, M., Davies, T. A., Dumitrica, P., Edwards, A. R., Galehouse, J. S., Packham, G. H., and van der Lingen, G. J., 1972. Australian-Antarctic continental drift, paleocirculation changes and Oligocene deep sea erosion: Nature Phys. Sci., v. 239 , p. $51-55$.

Larson, R. L. and Pitman, W. C., III, 1972. World-wide correlations of Mesozoic magnetic anomalies; and its implications: Geol. Soc. Am. Bull., v. 83, p. 3645-3662.

LePichon, X. and Heirtzler, J. R., 1968. Magnetic anomalies in the Indian Ocean and sea floor spreading: J. Geophys. Res., v. 73, p. 2101-2117.

McKenzie, D. and Sclater, J. G., 1971. Evolution of the Indian Ocean since the Late Cretaceous: Geophys. J. Roy. Astron. Soc., v. 25 , p. $437-528$.

Morgan, J., 1972. Plate motions and deep mantle convection: Geol. Soc. Am. Mem., v. 132, p. 7-22.

Simpson, E., Schlich, R., et al,, in press. Initial Reports of the Deep Sea Drilling Project, Volume 25: Washington (U.S. Government Printing Office).

Veevers, J. J., Jones, J. G., and Talent, J. A., 1971. India Australian stratigraphy and the configuration and dispersal of Gondwanaland: Nature, v. 229, p. 383-388.

von der Borch, C., Sclater, J. G., et al., 1974. Initial Reports of the Deep Sea Drilling Project, Volume 22: Washington (U.S. Government Printing Office).

Weissel, J. and Hayes, D., 1971. Asymmetric sea floor spreading south of Australia: Nature, v. 231, p. 518-522. 